\title{
Treatment of wastewater from a monosodium glutamate manufacturing plant using successive yeast and activated sludge systems
}

\author{
Qingxiang Yang ${ }^{\mathrm{a}, \mathrm{b}}$, Min Yang, ${ }^{\mathrm{a}, *}$, Shujun Zhang ${ }^{\mathrm{a}}$, Wenzhou $\mathrm{Lv}^{\mathrm{a}}$ \\ ${ }^{a}$ State Key Laboratory of Environmental Aquatic Chemistry, Research Center for Eco-Environmental Sciences, \\ Chinese Academy of Sciences, Beijing 100085, China \\ ${ }^{\mathrm{b}}$ Ministry of Education Key Laboratory for Marine Environmental Sciences, Center for Marine Environmental Sciences, \\ Xiamen University 361005, China
}

Received 22 March 2004; received in revised form 21 April 2004; accepted 29 September 2004

\begin{abstract}
Successive systems using yeast and activated sludge (AS) were developed to treat monosodium glutamate manufacturing wastewater (MSGW). The yeast system allowed over $80 \%$ removal of chemical oxygen demand (COD) and a rise of pH from 2.5 to 6.5 on treating MSGW directly (COD 25,000 mg/l and $\mathrm{NH}_{4}{ }^{+}-\mathrm{N} 19,000 \mathrm{mg} / \mathrm{l}$ ). Observation of the microbial community using a scanning electron microscope indicated that the two species of yeast (Candida halophila and Rhodotorula glutinis) were predominant in the biofilm reactor during 2 months of operation. The suspended solids (SS) of effluents from the yeast reactor were mainly composed of yeasts and fermentative bacteria used in glutamate production. This part of SS contained 55.8\% protein and 18 amino acids and could be utilized as a source of single cell protein (SCP) as animal food additive. The effluent from the yeast system was fed into the activated sludge system after $\mathrm{NH}_{4}{ }^{+}-\mathrm{N}$ was reduced to a level of $1000 \mathrm{mg} / \mathrm{l}$ through air stripping. The activated sludge system could remove $50-70 \%$ of the remaining COD further, and the effluent COD and SS were constantly below 1300 and $70 \mathrm{mg} / \mathrm{l}$, respectively. The combined system biologically removed about $95 \%$ COD from MSGW, and the COD could be further reduced to below $360 \mathrm{mg} / \mathrm{l}$ with coagulation under an $\mathrm{FeCl}_{3}$ dose of $1400 \mathrm{mg} / \mathrm{Fe} 1$.
\end{abstract}

(C) 2004 Elsevier Ltd. All rights reserved.

Keywords: Yeast; Activated sludge; Monosodium glutamate; High strength wastewater; Microbial community

\section{Introduction}

Environmental regulations developed in China have an impact on pollution produced by fermentative industries. Effluent from monosodium glutamate manufacturing plants is one of the most intractable fermentative wastewater because of its high strength of COD $(10,000-30,000 \mathrm{mg} / \mathrm{l})$, ammonium $(15,000-25,000 \mathrm{mg} / \mathrm{l})$, sulphate $(15,000-$ $30,000 \mathrm{mg} / \mathrm{l})$ and very low $\mathrm{pH}(\sim 2)$. Anaerobic processes are not feasible for this effluent due to the toxic inhibition of such high concentrations of ammonia and sulphate [1,2]. An air-stripping process under basic conditions is a commonly used technology for removal of high concentrations of

\footnotetext{
* Corresponding author. Fax: +861062923475.

E-mail address: yangmin@mail.rcees.ac.cn (M. Yang).
}

ammonia [3]. However, the alkali consumption will be very high because of the low $\mathrm{pH}$ and high concentration of organic acids. Treatment of such a high concentration of COD by conventional activated sludge processes consumes a lot of energy, resulting in high treatment costs [4]. Therefore, the efficient and economical treatment of such fermentative wastewater is becoming a big challenge.

Since the 1980s, a favourable process using such wastewater to produce yeast single cell protein (SCP) as an animal food additive has been developed in China [5]. There has long been a good market for this SCP. However, the technology required a special pure yeast strain, special fermentative tanks, a series of expensive sterile operations and the COD removal was normally below 70\% [6].

On the other hand, there have been many reports on yeast wastewater treatment technology since the end of 1970s, 
which is different from the traditional SCP production [710]. This technology uses highly adaptive yeasts to treat wastewater under aerobic and open conditions and the design is similar to conventional wastewater treatment processes, in which bacteria are predominant. Yeast technology is a potential process for treating MSGW because of its high endurance to low $\mathrm{pH}$ and high salinity, and the possibility of producing single cell protein from the organic pollutants in wastewater. In a previous report, we have demonstrated that more than $80 \%$ COD could be removed from MSGW using a mixture of two ammoniumtolerant yeasts (Candida halophila and Rhodotorula glutinis), and the $\mathrm{pH}$ of the wastewater increased with the removal of COD [11]. In this study, a two-step biological system using the yeast mixture and activated sludge was constructed, and ammonia stripping was put behind the yeast system for the purpose of reducing alkali consumption. The performance of the two-step biological system was evaluated through more than 2-month operation of benchscale and the possibility of using biomass from the yeast system as a source of single cell protein was also investigated.

\section{Materials and methods}

\subsection{Analytical methods and wastewater characterization}

The waste liquid of MSG fermentation was taken from an MSG manufacturing plant in Tianjin, China. A large part of biomass had been recovered as animal food additive through flocculation in the factory. Chemical oxygen demand (COD), total organic carbon (TOC) and $\mathrm{SO}_{4}{ }^{2-}$ were measured with a COD automatic detector (CTL-12, Huatong, China), TOC automatic detector (SHIMADZU TOC-500) and ion chromatography system (ICS-1500, DIONEX), respectively. According to standard methods [12], a weight difference method, spectrophotometric method with salicylic acid and ammonium molybdate spectrophotometric method were used to determine suspended solids (SS), $\mathrm{NH}_{4}{ }^{+}-\mathrm{N}$ and total phosphate (TP), respectively.

The characteristics of MSGW are listed in Table 1. The ratio of $\mathrm{BOD}_{5}$ to $\mathrm{COD}$ is about $75 \%$ suggesting that most of TOC in the wastewater can be used as carbon source. However, the ratio of $\mathrm{C}: \mathrm{N}: \mathrm{P}(1: 2.4: 0.005)$ is not appropriate for microbial growth. Phosphate is obviously not sufficient but the concentration of $\mathrm{NH}_{4}{ }^{+}-\mathrm{N}$ is too high. The $\mathrm{SS}$ remains
Table 1

Characteristics of monosodium glutamate wastewater (MSGW)

\begin{tabular}{ll}
\hline Items & Concentration \\
\hline $\mathrm{COD}(\mathrm{mg} / \mathrm{l})$ & $25,000 \pm 5000$ \\
$\mathrm{TOC}(\mathrm{mg} / \mathrm{l})$ & $8350 \pm 900$ \\
$\mathrm{BOD}_{5}(\mathrm{mg} / \mathrm{l})$ & $18,500 \pm 3500$ \\
$\mathrm{SS}(\mathrm{mg} / \mathrm{l})$ & $2100 \pm 900$ \\
$\mathrm{TP}(\mathrm{mg} / \mathrm{l})$ & $37.3 \pm 5.0$ \\
$\mathrm{NH}_{4}{ }^{+}-\mathrm{N}(\mathrm{mg} / \mathrm{l})$ & $19,000 \pm 1000$ \\
$\mathrm{SO}_{4}{ }^{2-}(\mathrm{mg} / \mathrm{l})$ & $22,800 \pm 2147$ \\
$\mathrm{Salinity}(\%)$ & 12 \\
pH & $2.5 \pm 0.5$ \\
Temperature $\left({ }^{\circ} \mathrm{C}\right)$ & 35 \\
\hline
\end{tabular}

The values are means \pm standard deviations of wastewater samples in five times.

very high and mainly composed of bacteria debris from the fermentation process.

\subsection{The two-step system for MSGW treatment}

The two-step biological treatment flow of MSGW is shown in Fig. 1. The systems were composed of a columntype yeast reactor (effective volume of $12.2 \mathrm{l}$ ) as reported in Yang [11] and a tank-type activated sludge reactor (Fig. 2). MSGW was fed continuously into the column reactor inoculated with the mixture of the two ammonium-tolerant yeasts (C. halophila and $R$. glutinis). The influent dilution was decreased from 1:9, 1:2, 2:1 (volume of MSGW to tap water) to raw wastewater. From Table 1, it is clear that phosphorus was not sufficient for microbial growth compared to the COD concentration. Phosphate was supplemented to the influent at a ratio of COD:P of 100:1. Effluents from the yeast reactor were adjusted to $\mathrm{pH}$ 11 using $\mathrm{NaOH}$ following the removal of biomass through centrifugation, and then recycled in a contact column type simulant air-stripping tower for four to five times to remove ammonia. The ratio of gas to liquid was 4000:1, and the residual $\mathrm{NH}_{4}{ }^{+}-\mathrm{N}$ was below $1000 \mathrm{mg} / \mathrm{l}$. The $\mathrm{pH}$ of wastewater was adjusted back to neutral and fed into the activated sludge system continuously. Operational conditions for the two reactors are described in Table 2.

\subsection{Analysis of biomass composition}

Excessive biomass from the yeast treatment column was collected by centrifugation and the cells were dried at $105{ }^{\circ} \mathrm{C}$ for $4 \mathrm{~h}$. Crude protein and crude fat were assayed by the method of Macro-Kjeldahl and Soxhelt ether extraction

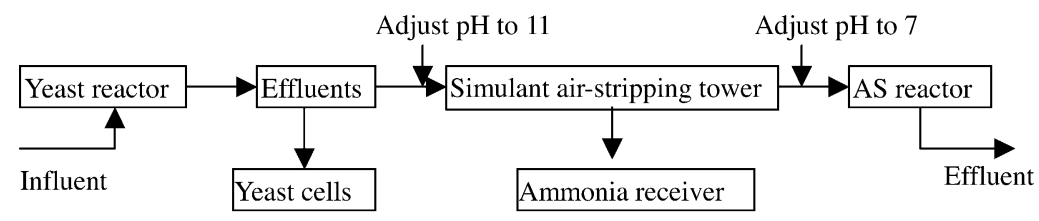

Fig. 1. The two-step biological treatment flow for MSGW. 
Table 2

Operational conditions of the two biological reactors

\begin{tabular}{lccccccl}
\hline Reactor & Effective volume $(\mathrm{l})$ & Influent COD $(\mathrm{mg} / \mathrm{l})$ & Feeding rate $(\mathrm{l} / \mathrm{d})$ & Influent $\mathrm{pH}$ & Air rate $(1 / \mathrm{min})$ & HRT $(\mathrm{h})$ & $T\left({ }^{\circ} \mathrm{C}\right)$ \\
\hline Yeast reactor & 12.2 & $8000-25,000 \pm 20 \%$ & 7.2 & $3.0 \pm 0.5$ & $30-100$ & 30,40 & 28 \\
AS reactor & 8.9 & $4000 \pm 500$ & 10.1 & $6.5 \pm 0.5$ & $30-100$ & 21 & 20 \\
\hline
\end{tabular}

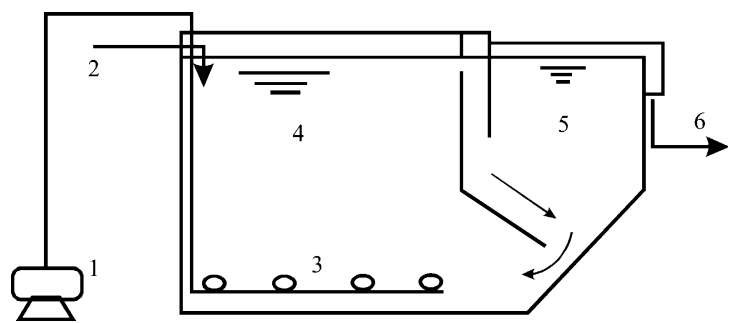

Fig. 2. Activated sludge (AS) reactor for MSGW treatment (1: air pump, 2: influents, 3: air mouth, 4: reaction tank with an effective volume of 8.91, 5: settlement tank, 6: effluents).

[13], respectively. The ash content was weighed after samples were combusted at $550-560{ }^{\circ} \mathrm{C}$ for $2 \mathrm{~h}$. Amino acids were analyzed with a Hitachi Amino acid autoanalyzer (model 825-10) after the samples were prepared by hydrolyzing whole cells in $6 \mathrm{~N} \mathrm{HCl}$ for $22 \mathrm{~h}$ at $110^{\circ} \mathrm{C}$ under vacuum. The content of nitrogen-free extracts was calculated by the following formula [13]:content of nitrogen-free extracts $=100 \%-($ crude protein + crude fat + crude ash) $\%$.

\section{Results and discussion}

\subsection{Treatment of MSGW by yeast system}

The yeast contact oxidation system was established by feeding diluted MSGW (volume of wastewater to tap water, 1:9) at low air rate after inoculation with $20 \mathrm{~g}$ wet cells of the mixed yeast. Then, the system was operated under the conditions specified in Table 2. The COD removal performance of yeast treatment system has been described in a previous report [11]. The influent condition was as

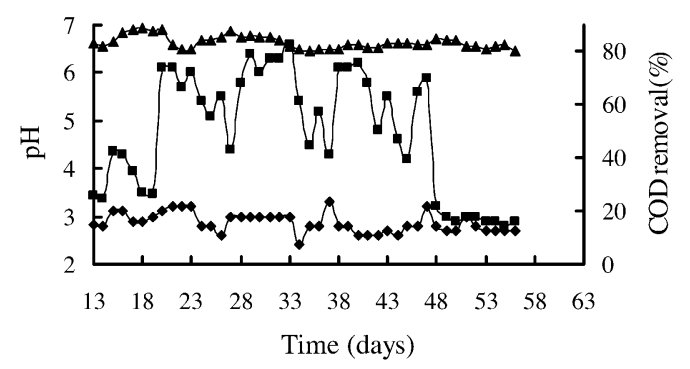

Fig. 3. Variation of $\mathrm{pH}$ value in yeast treatment system of MSGW. ( $\bullet$ ), influent $\mathrm{pH} ;(\boldsymbol{\square}) \mathrm{pH}$ value in yeast reactor; $(\boldsymbol{\Delta}) \mathrm{COD}$ removal; ratio of influent dilution (wastewater to tap water): 13-26 days, 1:2; 27-47 days, $2: 1 ; 48-57$ days, raw wastewater; HRT: $1-48$ days, $40 \mathrm{~h}$; 49-57 days, $30 \mathrm{~h}$ ). follows: $1-12$ days, $1: 3$; $13-26$ days, $1: 2$; 27-47 days, $2: 1$; $48-57$ days, raw wastewater. A COD removal over $80 \%$ was acquired over a period of nearly 2 months in spite of variation of influent COD from 6326 to $18977 \mathrm{mg} / \mathrm{l}$. After 48 days running, the organic loading rate (OLR) of the system was further increased to $18.7 \mathrm{~kg} / \mathrm{m}^{3} / \mathrm{d}$ as the hydraulic retention time (HRT) was shortened from 40 to $30 \mathrm{~h}$. This OLR was nearly 10 times that of an aerobic membrane bioreactor (1-2 $\mathrm{kg} \mathrm{COD} / \mathrm{m}^{3} /$ day) [12].

$\mathrm{pH}$ values in the yeast treatment system were monitored everyday from day 13 (shown in Fig. 3). At the first 26 days of running, the influent $\mathrm{pH}$ was controlled at 3.2 and the $\mathrm{pH}$ value of the yeast reactor rose to 5.5-6.5 as a result of consumption of acidic organic substances. The $\mathrm{pH}$ in the reactor did not change much when the influent $\mathrm{pH}$ decreased to around 2.5-3.0 with the decrease of MSGW dilution rate. However, the $\mathrm{pH}$ in the reactor declined to around 3 when the HRT was shortened to $30 \mathrm{~h}$ from day 49 , indicating that a relatively long HRT was required to maintain the effluent $\mathrm{pH}$ at $>5.0$. However, Fig. 3 demonstrates that the COD removal of the yeast system was not affected perceivably by the variation of $\mathrm{pH}$ in the reactor.

Compared to the conventional anaerobic or aerobic treatment systems of MSGW [2,4], the yeast reactor was distinguished in high efficiency, high COD load and tolerance to extreme wastewater conditions (low $\mathrm{pH}$ and high salinity). After this step of treatment, over $80 \%$ COD was removed and the $\mathrm{pH}$ value of the wastewater rose to 5.06.5 under a proper HRT, which was very helpful for ammonia removal in succession and could save a large amount of alkali consumption.

During 2-month operation, variations of SS from the yeast system were also monitored from day 21 (Fig. 4). The influent SS fluctuated widely from 2000 to $4000 \mathrm{mg} / \mathrm{l}$. The effluent SS

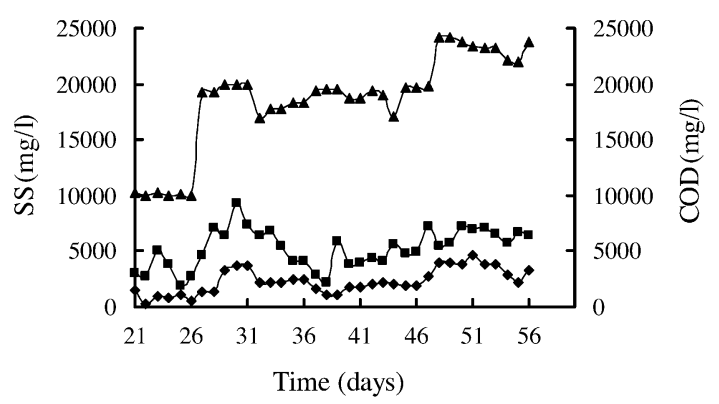

Fig. 4. SS Variation with COD load in yeast treatment system of MSGW $(\diamond)$ influent SS; $(\boldsymbol{\square})$ effluent SS; $(\boldsymbol{\Delta})$ influent COD; ratio of influent dilution (wastewater to tap water): $21-26$ days, $1: 2$; $27-47$ days, $2: 1$; 48-57 days, raw wastewater; HRT: 1-48 days, $40 \mathrm{~h}$; 49-57 days, $30 \mathrm{~h}$ ). 

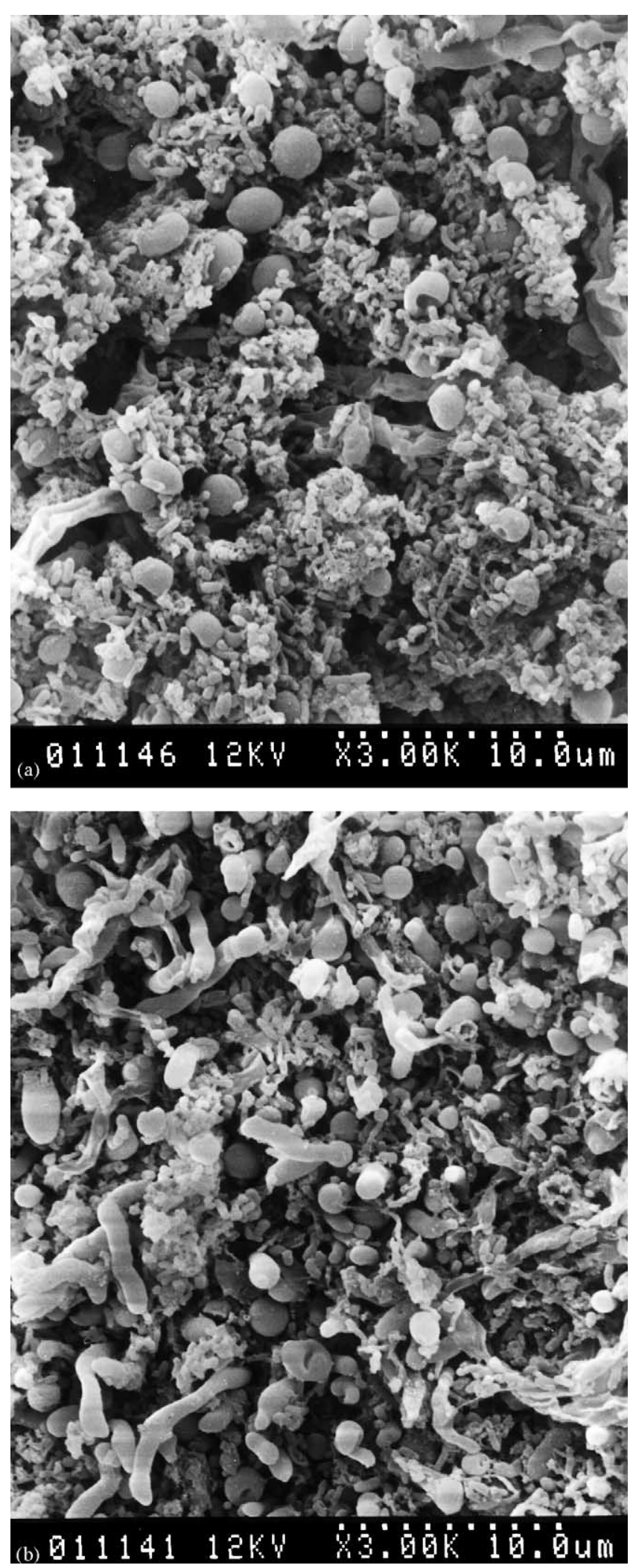

Fig. 5. Microbial community in the wads of yeast system under SEM $(\times 300)$ (a, lower part; b, upper part). varied with the influent SS, and was about $2500 \mathrm{mg} / \mathrm{l}$ higher than that. The SS difference between the effluent and influent can be considered as biomass produced during yeast treatment. Microscopic observation on the effluent SS demonstrated that the main components were the two yeast isolates and the bacteria used in glutamate fermentation.

Application of isolated microorganisms under non-sterile environments has long been a peradventure. After 2-month operation of the yeast treatment system, two parts of wads (upper and lower) in the column reactor were observed using a scanning electron microscope (SEM) to check the microbial community (Fig. 5).

The microbial communities were different between the two parts of wads in the column reactor and there were more bacteria present in the lower part. These bacteria had the same morphological characteristics as those present in fermentative wastewater and might be residual cells coming from influent. The upper part was mainly composed of two different shapes of yeast cells, which were identical with those of C. halophila and R. glutinis (Fig. 6) inoculated in the system. It is clear that $C$. halophila and $R$. glutinis could keep predominance in the treatment system even after 2month non-sterile running. High salinity and high concentrations of ammonia provided a favourable environment for the predominant growth of ammonia-tolerant yeasts.
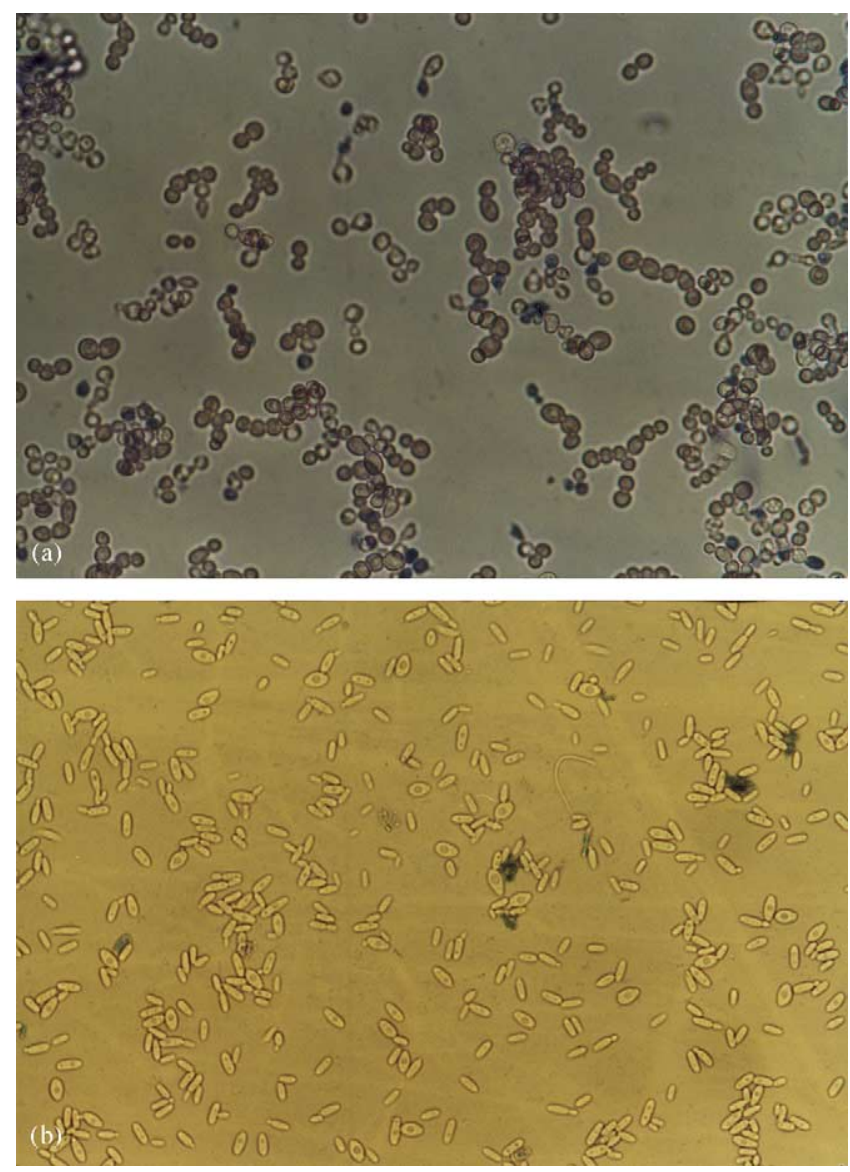

Fig. 6. Yeast isolates used in the yeast reactor (under microscope of $40 \times 10)($ a, Candida halophila; b, Rhodotorula glutinis). 


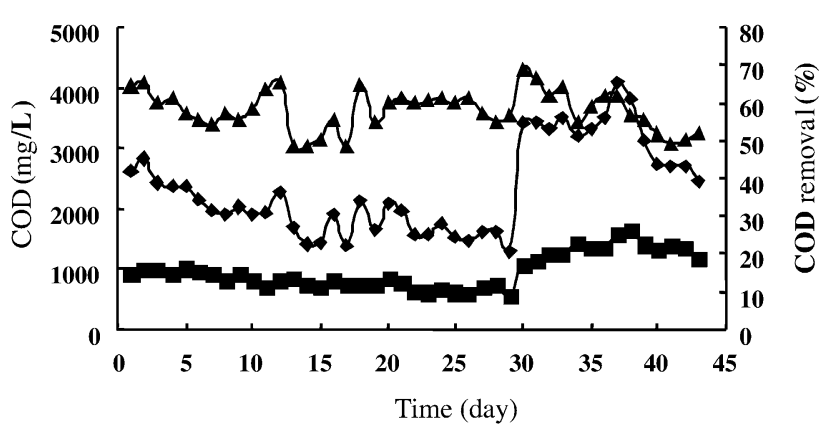

Fig. 7. Further COD removal of MSGW in activated sludge system $((\diamond)$, influent COD; ( $\boldsymbol{\square}$,) effluent COD; ( $\boldsymbol{\Delta}$,$) COD removal. Variation of influent$ COD corresponded to the effluents of yeast system in different treatment phases.).

\subsection{Further treatment of MSGW by activated sludge system}

The effluent from the yeast reactor was further fed into the activated sludge (AS) system following the removal of most of SS and ammonia. Fig. 7 shows the important parameters of the AS system during near 2-month running. During the first 30 days running, the influent COD was around $2000 \mathrm{mg} / \mathrm{l}$ and a stable COD removal around $60 \%$ was obtained. A COD removal of $50-70 \%$ was maintained even when the influent COD was increased to around $3500 \mathrm{mg} / \mathrm{l}$. The residual COD in the effluent from the AS reactor was about $1300 \mathrm{mg} / \mathrm{l}$, which was recalcitrant to biodegradation. Batch tests using $\mathrm{FeCl}_{3}$ as coagulant showed that this part of COD could be further reduced to below $360 \mathrm{mg} / \mathrm{l}$ through coagulation under an $\mathrm{FeCl}_{3}$ dose of $1400 \mathrm{mg} / \mathrm{l}$. The effluent $\mathrm{pH}$ and $\mathrm{SS}$ from AS reactor was constant at 6-7 and lower than $70 \mathrm{mg} / \mathrm{l}$, respectively.

Altogether, the two-step biological treatment systems could remove 95\% COD from raw MSGW (COD $25,000 \mathrm{mg} / \mathrm{l}, \mathrm{NH}_{4}{ }^{+}-\mathrm{N}$ 19,000 mg/l). However, further study is required to find a more economic way to recover ammonia and $\mathrm{SO}_{4}{ }^{2-}$ from MSGW.

Table 3

Contents of ammonia acids in excessive biomass from yeast reactor

\begin{tabular}{llll}
\hline Items & $\begin{array}{l}\text { Results } \\
\text { (\%/dry weight })\end{array}$ & Items & $\begin{array}{l}\text { Results } \\
\text { (\%/dry weight })\end{array}$ \\
\hline Asp & 3.94 & Leu & 3.18 \\
Thr & 1.92 & Tyr & 1.40 \\
Ser & 1.93 & Phe & 1.69 \\
Glu & 6.46 & Lys & 2.31 \\
Gly & 2.08 & $\mathrm{NH}_{3}$ & 2.91 \\
Ala & 3.20 & His & 0.74 \\
Cys-cys & - & Arg & 2.01 \\
Val & 2.37 & Pro & 1.54 \\
Met & 0.64 & Trp & - \\
Ile & 2.43 & Total & 40.75 \\
\hline
\end{tabular}

The data are means of three samples and the standard deviations were within $0.5 \%$ of the mean absolute values.

\subsection{Nourishment evaluation of excess biomass from the yeast reactor}

MSGW is a kind of pure wastewater containing no harmful components and is suitable to be utilized as raw material for SCP production. It is calculated that about 4-5 g $\mathrm{SCP}$ could be produced from $20 \mathrm{~g}$ COD. This part of the biomass contained $57.9 \%$ crude protein, $6.4 \%$ crude fat, $19.9 \%$ nitrogen-free extract and $5.0 \%$ crude ash. The protein content was higher than that of Saccharomyces carlsbergensis and near that of fishmeal, which are normally used in animal food additives as high protein sources [13]. There were 18 amino acids contained (shown in Table 3 ) in the biomass. The excess biomass from the yeast system was, therefore, a kind of good SCP with a high protein and low fat. Compared to conventional SCP production, the yeast treatment system of MSGW in this study was a continuous process without sterile operation and the set-up of treatment was a biofilm reactor instead of a fermentative tank, which could save a lot of labour and cost. The recovery of this part of SCP could counteract some part of the cost of wastewater treatment.

\section{Conclusion}

A two-step system containing successive reactors of yeast and activated sludge was developed to treat high strength MSGW. The yeast system removed over $80 \%$ COD and increased pH from 2.5 to 5.0-6.0 at an HRT of $40 \mathrm{~h}$, which could save large amount of alkali for the following ammonia removal. The predominant growth of yeast isolates under non-sterile condition could be steadily maintained in the system during 2-month operation. The excess biomass from the yeast reactor contained a high concentration of protein and 18 kinds of amino acids, showing that the biomass was a promising SCP. The two-step biological treatment system could totally remove $95 \%$ COD from MSGW.

\section{Acknowledgements}

The authors would like to acknowledge the committee of NSFC (National Natural Science Foundation of China) and the Science Foundation of Henan Science and Technology Office for the financial supports (nos. 50278095 and 0411032400).

\section{References}

[1] Sabine K, Sanjeev KD, Siemen V, Vermaat JE. The effect of $\mathrm{pH}$ variation at the ammonium/ammonia equilibrium in wastewater and its toxicity to Lemna gibba. Aquat Bot 2001;71:71-8.

[2] Hui P. Anaerobic treatment of wastewater discharged from monosodium glutamate manufacturing by sulphuric acid method. Environ Pollut Prev 1995;17:10-3 [in Chinese]. 
[3] Zhang Z, Lin R, Jin R. Drainage engineering. Beijing: China Architecture Industry Press; 2000. p. 306-8.

[4] Chen L. Treatment of monosodium glutamate wastewater using SBR activated sludge. J China Text Univ 1996;22(4):79-85 [in Chinese].

[5] Li S, Li G, Yang S. Treatment of maize starch industrial wastewater using yeasts. Wat Treat Technol 2002;28:227-9.

[6] Chen Z, Shen C, Chen G. Process of monosodium glutamate manufacturing. Beijing: China Light Industry Press; 1990 p. 1-19 [in Chinese].

[7] Zheng S, Yang M, Li P. Seed yeast cultivation for salad oil manufacturing wastewater treatment. J Environ Sci 2002;14:39-43.

[8] Zheng S, Yang M, Liu F, Lv W. Study on expansion during the treatment of salad oil manufacturing wastewater by yeasts. Environ Technol 2001;22:533-42.
[9] Chigusa K, Hasegawa T, Yamamoto N, Watanabe Y. Treatment of Wastewater from Oil Manufacturing Plant by Yeasts. Wat Sci Technol 1996;34:51-8.

[10] Moriya K, Iefuji H, Shimoi H, Sato S, Tadenuma M. Treatment of distillery wastewater discharged from beet molasses-spirits production using yeast. J Ferment Bioeng 1990;69:138-40.

[11] Yang Q, Yang M, Hei L, Zheng S. Using ammonium-tolerant yeast isolates: Candida halophila and Rhodotorula glutinis to treat high strength fermentative wastewater. Environ Technol 2003;24:383-90.

[12] APHA. Standard methods for water and wastewater examination. 19th ed. Washington DC, USA: American Public Health Association; 1995. p. $2-53$.

[13] Huang D, Li F, Zhao Q. Forage handbook. Beijing: Science and Technology Press; 1984. p. 301-522 [in Chinese]. 